\title{
PENGETAHUAN TENTANG COVID 19 MAHASISWA KEPERAWATAN UNIVERSITAS BORNEO TARAKAN
}

\author{
Alfianur \\ Fakultas Ilmu Kesehatan Universitas Borneo Tarakan \\ Email : alfianoer@gmail.com
}

\begin{abstract}
Abstrak
Covid 19 merupakan penyakit infeksi saluran pernapasan yang disebabkan oleh coronavirus, penyakit ini telah menjadi pandemik, mudahnya penularan penyakit ini menyebabkan hampir semua Negara di dunia mengalami wabah ini. Pencegahan penyakit coronavirus ini telah banyak disampaikan oleh WHO dan pemerintah seperti, mencuci tangan dengan sabun pada air yang mengalir, menutup wajah dengan Masker, menjaga jarak, membatasi aktifitas dengan dirumah saja. Keberhasilan pencegahan penyakit ini yang tergantung pada kedisiplinan dan kepatuhan masyarakat melaksanakan himbauan pemerintah Tujuan dari penelitian ini adalah untuk menggambarkan tingkat pengetahuan responden tentang Covid 19. Jenis penelitian ini adalah penelitian kuantitatif dengan desain Cross sectional. Sampel penelitian ini adalah Mahasiswa Jurusan Keperawatan. Menggunakan total sampling dan pengolahan data menggunakan pendekatan statistika deskriptif (distribusi frekuensi). Hasil analisis data didapatkan responden memiliki tingkat pengetahuan yang Baik sebanyak 113 orang $(83 \%)$ sisanya memiliki pengetahuan di tingkat cukup sebanyak 24 orang(17\%).
\end{abstract}

Kata Kunci: Pengetahuan, Covid 19

\begin{abstract}
Knowledge About Covid 19 Nursing Students University of Borneo Tarakan. Covid 19 is a respiratory tract infection caused by the coronavirus, this disease has become a pandemic, the easy transmission of this disease has caused almost all countries in the world to experience this outbreak. The prevention of coronavirus disease has been conveyed by WHO and the government such as washing hands with soap in running water, covering faces with masks, maintaining distance, limiting activities at home. The success of preventing this disease which depends on the discipline and compliance of the community in carrying out the government's appeal. The purpose of this study is to analyze the relationship between the level of knowledge about Covid 19 and adherence to disease prevention. This research is a quantitative study with a crosssectional design. The sample of this research is the Nursing Department Students. Using total sampling and data processing using a descriptive statistical approach (Chi-Square / Fisher Exact test and frequency distribution). The results of data analysis showed that the respondents had a good level of knowledge as many as 113 people (83\%), the rest had sufficient knowledge as many as 24 people (17\%)
\end{abstract}

Keywords: Knowledge, Covid 19 


\section{Pendahuluan}

Covid 19 merupakan penyakit infeksi saluran pernapasan yang disebabkan oleh coronavirus, penyakit ini telah menjadi pandemik, mudahnya penularan penyakit ini menyebabkan hampir semua Negara di dunia mengalami wabah ini. Hingga hari 16 Mei 2020 berdasarkan data yang dirilis oleh WHO ada sebanyak 4.434.653 kasus dengan angka kematian 302.169. di Indonesia terdapat 17.025 kasus dengan 1.089 kematian. Sedangkan untuk wilayah provinsi Kalimantan Utara terdapat 153 kasus positif dengan 1 kematian. Banyak faktor yang menyebabkan tingginya angka kejadian kasus suatu wilayah mulai dari tingkat kepadatan penduduk, kemudahan pergerakan orang dari suatu wilayah ke wilayah lainnya dan juga faktor kedisiplinan dalam melaksanakan anjuran pemerintah terkait bagaimana cara pencegahan penyakit ini.

Pencegahan penyakit coronavirus ini telah banyak disampaikan oleh WHO dan pemerintah seperti, mencuci tangan dengan sabun pada air yang mengalir, menutup wajah dengan Masker, menjaga jarak, membatasi aktifitas dengan dirumah saja. Sangat penting mengetahui tingkat pengetahuan masyarakat tentang Covid 19 dalam hal ini mahasiswa Keperawatan dan belum ada penelitian sebelumnya yang meneliti mengenai hal tersebut. Adapun tujuan dari penelitian ini adalah untuk menggambarkan tingkat pengetahuan responden tentang Covid 19. Keberhasilan pencegahan penyakit ini yang tergantung pada pengetahuan, kedisiplinan dan kepatuhan masyarakat melaksanakan himbauan.

\section{Metode}

Jenis penelitian ini adalah penelitian kuantitatif dengan desain Cross sectional. Sampel penelitian ini adalah Mahasiswa Jurusan Keperawatan. Menggunakan total sampling dan pengolahan data menggunakan pendekatan statistika deskriptif (distribusi frekuensi). Pengumpulan data dalam penelitian ini menggunakan kuesioner yang dibuat sendiri oleh peneliti dengan terlebih dahulu melakukan uji reliabilitas dan validitas. Kemudian dalam proses penelitian peneliti menjamin pelaksanaannya tetap memperhatikan prinsip-prinsip etik dalam penelitian.

\section{Hasil}

Pengumpulan data penelitian dilakukan di Jurusan keperawatan dengan responden mahasiswa jurusan sebanyak 137 orang. Pengumpulan data dilakukan pada bulan Agustus dengan mengisi google form karena mempertimbangkan kondisi pandemik covid 19 dan Universitas memutuskan melakukan pembelajaran dalam jaringan selama batas 
waktu yang tidak ditentukan. Melalui proses pengumpulan data berikut kami uraikan datadatanya.

1. Karakteristik Responden

Tabel.1 Karakteristik berdasarkan Semester, Umur, Asal Kabupaten/Kota dan Jenis Kelamin

\section{Karakteristik Frekuensi Persentase}

Semester

\begin{tabular}{llcc}
\hline 1. & 3 & 62 & 45 \\
\hline 2. & 5 & 75 & 55 \\
\hline 3. & Total & $\mathbf{1 3 7}$ & $\mathbf{1 0 0}$ \\
\hline
\end{tabular}

\section{Umur}

1. $18 \quad 9 \quad 6$

\begin{tabular}{llcc}
\hline 2. & 19 & 48 & 35 \\
\hline 3. & 20.00 & 43 & 31 \\
\hline 4. & 21.00 & 28 & 20 \\
\hline 5. & 22.00 & 6 & 4 \\
\hline 6. & 23.00 & 1 & 1 \\
\hline 7. & 24.00 & 2 & 2 \\
\hline 8. & Total & $\mathbf{1 3 7}$ & $\mathbf{1 0 0}$ \\
\hline
\end{tabular}

Asal Kabupaten/Kota

\begin{tabular}{llcc}
\hline 1. & Tarakan & 70 & 51 \\
\hline 2. & Bulungan & 8 & 6 \\
\hline 3. & Nunukan & 33 & 24 \\
\hline 4. & Malinau & 10 & 7 \\
\hline 5. & KTT & 6 & 4 \\
\hline 6. & Berau & 6 & 4 \\
\hline 7. & Lainnya & 4 & 3 \\
\hline 8. & Total & $\mathbf{1 3 7}$ & $\mathbf{1 0 0}$
\end{tabular}

Jenis Kelamin

\begin{tabular}{llcc}
\hline 1. & Perempuan & 124 & 90 \\
\hline 2. & Laki-laki & 13 & 10 \\
\hline 3. & Total & $\mathbf{1 3 7}$ & $\mathbf{1 0 0}$ \\
\hline
\end{tabular}

Dari tabel tergambar bahwa responden terbanyak adalah mahasiswa semester 5 dengan persentase 55\%, umur responden terbanyak adalah 19 tahun sebanyak 35\%, asal kota responden terbanyak adalah kota tarakan sebanyak $51 \%$ dan $90 \%$ responden berjenis kelamin perempuan.

2. Tingkat pengetahuan mahasiswa keperawatan tentang covid 19

Tabel.2 persentase tingkat pengetahuan responden

\begin{tabular}{lcc} 
Pengetahuan & Frekuensi & Persentase \\
\hline Cukup & 24 & 17.5 \\
\hline Baik & 113 & 82.5 \\
\hline Total & 137 & 100.0 \\
\hline
\end{tabular}

Berdasarkan tabel diatas tergambar bahwa dari pengumpulan data didapatkan responden memiliki tingkat pengetahuan yang Baik sebanyak 113 orang (83\%) sisanya memiliki pengetahuan di tingkat Cukup sebanyak 24 orang $(17 \%)$.

Tabel. 3 Distribusi persentase pengetahuan responden mengenai covid 19

\begin{tabular}{clll}
\hline \multirow{2}{*}{ No } & \multicolumn{1}{c}{ Pernyataan } & \multicolumn{2}{c}{ Jumlah (\%) } \\
\cline { 3 - 4 } & & \multicolumn{1}{c}{ Benar } & Salah \\
\hline 1 & $\begin{array}{l}\text { Penyakit covid 19 } \\
\text { sama dengan penyakit } \\
\text { Influenza }\end{array}$ & $\begin{array}{l}75(55 \\
\%\end{array}$ & $\begin{array}{c}62(45 \\
\%)\end{array}$ \\
\hline 2 & $\begin{array}{l}\text { Penyakit Covid 19 } \\
\text { adalah penyakit yang } \\
\text { disebabkan karena } \\
\text { Kurang Gizi. }\end{array}$ & & \\
\hline
\end{tabular}




\begin{tabular}{|c|c|c|c|}
\hline 3 & $\begin{array}{l}\text { Penyakit Covid } 19 \\
\text { disebabkan } \\
\text { bakteri }\end{array}$ & $\begin{array}{c}79 \\
(58 \%)\end{array}$ & $\begin{array}{c}58 \\
(42 \%)\end{array}$ \\
\hline 4 & $\begin{array}{lr}\text { Penyakit } & \text { covid } 19 \\
\text { adalah } & \text { penyakit } \\
\text { menular } & \end{array}$ & $\begin{array}{c}137 \\
(100 \%)\end{array}$ & 0 \\
\hline 5 & $\begin{array}{l}\text { Penyakit covid } 19 \\
\text { selalu menimbulkan } \\
\text { gejala }\end{array}$ & $\begin{array}{c}54 \\
(39 \%)\end{array}$ & $\begin{array}{c}83 \\
(61 \%)\end{array}$ \\
\hline 6 & $\begin{array}{l}\text { Penyakit Covid } 19 \\
\text { hanya menjangkiti } \\
\text { lanjut usia }\end{array}$ & $\begin{array}{c}127 \\
(93 \%)\end{array}$ & $\begin{array}{c}10 \\
(7 \%)\end{array}$ \\
\hline 7 & $\begin{array}{llr}\text { Covid } & 19 & \text { bisa } \\
\text { menyebar } & \text { ke } & \text { manusia } \\
\text { melalui } & & \text { hewan } \\
\text { peliharaan } & & \end{array}$ & $\begin{array}{c}69 \\
(50 \%)\end{array}$ & $\begin{array}{c}68 \\
(50 \%)\end{array}$ \\
\hline 8 & $\begin{array}{l}\text { Kuman penyebab } \\
\text { Covid } 19 \text { hanya dapat } \\
\text { masuk melalui hidung } \\
\text { dan mulut }\end{array}$ & $\begin{array}{c}44 \\
(32 \%)\end{array}$ & $\begin{array}{c}93 \\
(68 \%)\end{array}$ \\
\hline 9 & $\begin{array}{l}80 \% \text { dari kasus Covid } \\
19 \text { merupakan } \\
\text { penyakit ringan }\end{array}$ & $\begin{array}{c}33 \\
(24 \%)\end{array}$ & $\begin{array}{c}104 \\
(76 \%)\end{array}$ \\
\hline 10 & $\begin{array}{l}\text { Salah satu tanda dan } \\
\text { gejala penderita Covid } \\
19 \text { adalah Demam } \\
\text { tinggi. }\end{array}$ & $\begin{array}{c}133 \\
(97 \%)\end{array}$ & $4(3 \%)$ \\
\hline 11 & $\begin{array}{l}\text { Penderita } \quad \text { positif } \\
\text { Covid } 19 \text { selalu } \\
\text { mengalami sesak }\end{array}$ & $\begin{array}{c}24 \\
(18 \%)\end{array}$ & $\begin{array}{c}113 \\
(82 \%)\end{array}$ \\
\hline 12 & $\begin{array}{l}\text { Penderita Covid } 19 \\
\text { kadang mengeluhkan } \\
\text { gangguan penciuman. }\end{array}$ & $\begin{array}{c}73 \\
(53 \%)\end{array}$ & $\begin{array}{c}64 \\
(47 \%)\end{array}$ \\
\hline 13 & $\begin{array}{l}\text { PDP adalah pasien } \\
\text { yang positif Covid } 19\end{array}$ & $\begin{array}{c}85 \\
(62 \%)\end{array}$ & $\begin{array}{c}52 \\
(38 \%)\end{array}$ \\
\hline 14 & $\begin{array}{llr}\text { Penderita } & & \text { Positif } \\
\text { Covid } & 19 & \text { bila }\end{array}$ & $\begin{array}{c}43 \\
(31 \%)\end{array}$ & $\begin{array}{c}94 \\
(69 \%)\end{array}$ \\
\hline
\end{tabular}

\begin{tabular}{|c|c|c|c|}
\hline & $\begin{array}{l}\text { pemeriksaan Rapid } \\
\text { Tes Nya Reaktif }\end{array}$ & & \\
\hline 15 & 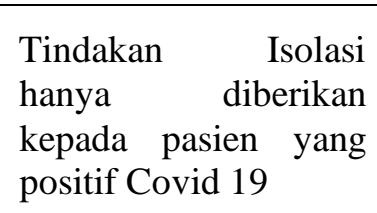 & $\begin{array}{c}76 \\
(56 \%)\end{array}$ & $\begin{array}{c}61 \\
(44 \%)\end{array}$ \\
\hline 16 & $\begin{array}{l}\text { Pencegahan penularan } \\
\text { Covid } 19 \text { cukup } \\
\text { dengan menggunakan } \\
\text { masker }\end{array}$ & $\begin{array}{c}85 \\
(62 \%)\end{array}$ & $\begin{array}{c}52 \\
(38 \%)\end{array}$ \\
\hline 17 & $\begin{array}{lr}\text { Dalam perkembangan } \\
\text { penyakit } 10 & -15 \% \\
\text { mengalami } & \text { gagal } \\
\text { pernapasan } & \text { yang } \\
\text { parah. } & \end{array}$ & $\begin{array}{c}127 \\
(93 \%)\end{array}$ & $\begin{array}{c}30 \\
(7 \%)\end{array}$ \\
\hline 18 & $\begin{array}{l}\text { Membilas hidung atau } \\
\text { berkumur dengan air } \\
\text { asin dapat mencegah } \\
\text { penularan. }\end{array}$ & $\begin{array}{c}103 \\
(75 \%)\end{array}$ & $\begin{array}{c}34 \\
(25 \%)\end{array}$ \\
\hline 19 & $\begin{array}{l}\text { Virus akan mati ketika } \\
\text { cuaca akan semakin } \\
\text { hangat }\end{array}$ & $\begin{array}{c}63 \\
(46 \%)\end{array}$ & $\begin{array}{c}74 \\
(54 \%)\end{array}$ \\
\hline 20 & $\begin{array}{ll}\text { Antibiotik } & \text { diperlukan } \\
\text { untuk } & \text { mengobati } \\
\text { Covid 19 } & \end{array}$ & $\begin{array}{c}20 \\
(22 \%)\end{array}$ & $\begin{array}{c}107 \\
(78 \%)\end{array}$ \\
\hline 21 & $\begin{array}{lr}\text { Cairan non alcohol } \\
\text { dapat } & \text { digunakan } \\
\text { sebagai } & \text { cairan } \\
\text { pembersih } & \text { (hand } \\
\text { sanitizer) } & \end{array}$ & $\begin{array}{c}72 \\
(53 \%)\end{array}$ & $\begin{array}{c}65 \\
(47 \%)\end{array}$ \\
\hline 22 & $\begin{array}{lr}\begin{array}{l}\text { Meminum } \\
\text { panas }\end{array} & \begin{array}{r}\text { minuman } \\
\text { dapat }\end{array} \\
\text { membunuh } & \text { Kuman } \\
\text { Penyebab Covid } 19\end{array}$ & $\begin{array}{c}87 \\
(64 \%)\end{array}$ & $\begin{array}{c}50 \\
(36 \%)\end{array}$ \\
\hline 23 & $\begin{array}{l}\text { 2-5\% kasus Covid } 19 \\
\text { mengakibatkan } \\
\text { kematian }\end{array}$ & $\begin{array}{c}132 \\
(96 \%)\end{array}$ & $5(4 \%)$ \\
\hline 24 & $\begin{array}{l}\text { Sebagai tindakan } \\
\text { pencegahan Covid } 19\end{array}$ & $\begin{array}{c}115 \\
(84 \%)\end{array}$ & $\begin{array}{c}22 \\
(16 \%)\end{array}$ \\
\hline
\end{tabular}




\begin{tabular}{llcc}
\hline \multicolumn{3}{l}{$\begin{array}{l}\text { masker bedah dapat } \\
\text { digunakan kembali } \\
\text { setelah dicuci }\end{array}$} & \\
\hline 25 & $\begin{array}{l}\text { Hingga saat ini belum } \\
\text { ada Vaksin yang bisa } \\
\text { melindungi kita dari } \\
\text { Virus Covid 19 }\end{array}$ & & \\
\hline
\end{tabular}

Dari tabel diatas dapat tergambar bahwa $137(100 \%)$ responden mengetahui bahwa covid 19 merupakan penyakit yang menular. Sebanyak 83(64\%) responden belum mengetahui bahwa Penyakit covid 19 tidak selalu selalu menimbulkan gejala, sebanyak 113 (82\%) belum mengetahui bahwa Penderita positif Covid 19 tidak selalu mengalami sesak, Sebanyak 107 (78\%) belum mengetahui bahwa antibiotik tidak efektif mengobati covid 19, sebanyak 115 (84\%) mengetahui bahwa Sebagai tindakan pencegahan Covid 19 masker bedah tidak dapat digunakan kembali setelah dicuci dan sebanyak 123 (90\%) mengetahui bahwa hingga saat ini belum ada Vaksin yang bisa melindungi kita dari Virus Covid 19.

\section{Pembahasan}

Pengetahuan memegang peranan penting dalam penentuan perilaku yang utuh karena pengetahuan akan membentuk kepercayaan yang selanjutnya dalam mempersepsikan kenyataan, memberikan dasar bagi pengambilan keputusan dan menentukan perilaku terhadap objek tertentu (Novita dkk, 2018).

Berdasarkan pengumpulan data didapatkan responden memiliki tingkat pengetahuan yang Baik sebanyak 113 orang (83\%) sisanya memiliki pengetahuan di tingkat Cukup sebanyak 24 orang (17\%). yang dimaksud dengan pengetahuan dalam penelitian ini adalah hasil dari tahu dan tindakan dari mengingat suatu hal serta akan terjadi bila seseorang melakukan pengamatan atau kontak terhadap suatu objek tertentu. Menurut Notoatmodjo (2007) pengetahuan seseorang dipengaruhi oleh faktor pendidikan, pekerjaan, usia, minat dan pengalaman. Pendidikan merupakan hal yang sangat penting sebagai sarana untuk mendapatkan informasi misalnya di bidang kesehatan sehingga memberikan pengaruh positif bagi kualitas hidup seseorang. Pendidikan mempengaruhi seseorang untuk berperan serta dalam pembangunan dan umumnya semakin tinggi tingkat pendidikan seseorang akan semakin mudah dalam menerima informasi semakin lama mahasiswa menempuh perkuliahan maka semakin tinggi tingkat pengetahuan.

Pengetahuan tentang bagaimana cara dalam pemeliharaan kesehatan, bagaimana menghindari penyakit, maka hal tersebut dapat 
membuat pengetahuan masyarakat meningkat (Priyanto, 2018). Meningkatnya pengetahuan mengenai penyakit Covid-19 merupakan penting agar seseorang dapat memahami bagaimana melakukan pencegahan penularan sehingga jumlah kasus penyakit Covid-19 tidak terus meningkat. Pengetahuan seseorang dapat diartikan sebagai hasil tahu mengenai penyakitnya, memahami penyakitnya, cara pencegahan, pengobatan dan komplikasinya (Mona, 2020). Suatu perilaku baru pada orang dewasa mulai terbentuk pada domain kognitif dalam arti seseorang tahu terlebih dahulu terhadap stimulus yang berupa materi atau objek di luarnya, sehingga melahirkan pengetahuan baru dan akan terbentuk dalam sikap maupun tindakan.

\section{Kesimpulan}

Berdasarkan hasil dari penelitian dapat ditarik kesimpulan bahwa tingkat pengetahuan mahasiswa keperawatan Universitas Borneo Tarakan tentang covid 19 Baik sebanyak 113 orang $(83 \%)$ sisanya memiliki pengetahuan di tingkat Cukup sebanyak 24 orang(17\%)

\section{Saran}

Berdasarkan hasil penelitian yang kami dapatkan ada saran-saran yang ingin kami sampaikan:

1. Perlunya peningkatan kesadaran mahasiswa Jurusan Keperawatan dalam melakukan tindakan pencegahan Covid 19 dengan konseling, edukasi.

2. Agar keluarga dapat memberikan dukungan penghargaan, pendekatan emosional dan aktif dalam monitoring pencegahan penularan covid 19.

\section{Referensi}

Albery, Ian P. \& Marcus Munafo. (2011). Psikologi Kesehatan Panduan Lengkap dan Komprehensif Bagi Studi Psikologi Kesehatan. Cetakan I. Palmall. Yogyakarta

Arikunto (2010) Prosedur Penelitian Suatu Pendekatan Praktik. Rineka Cipta. Jakarta Azwar, S. (2013). Sikap manusia teori dan pengukurannya. Yogyakarta: pusat pelajar Chaplin, JP (2008). Kamus Lengkap Psikologi. Raja Grafindo Persada. Jakarta

Dahlan, MS. (2010). Besar Sampel dan Cara Pengambilan Sampel Dalam Penelitian Kedokteran dan Kesehatan. Edisi 3. Salemba Medika. Jakarta. 
Kozier. (2010). Buku Ajar Praktik Keperawatan Klinis. Edisi 5. EGC Jakarta

Kementerian Kesehatan. (2020). Pedoman COVID REV-4

McLeod. S. A (2007). Milgram Experiment. Retrieved from http://www.simplypsychology.org/mil gram.html

Mona, Nailul. (2020). Konsep Isolasi Dalam Jaringan Sosial Untuk Meminimalisasi Efek Contagious (Kasus Penyebaran Virus Corona di Indonesia). Jurnal Sosial Humaniora Terapan. Vol. 2 No.2. Universitas Indonesia : Program Studi Periklanan Kreatif Program Pendidikan Vokasi

Notoatmodjo, S. (2010). Promosi Kesehatan Teori dan Aplikasi. PT Rineka Cipta. Jakarta

Notoatmodjo, S. (2012). Promosi Kesehatan dan Perilaku Kesehatan. PT Rineka Cipta. Jakarta

Novita, dkk. (2014). Tingkat Pengetahuan Tentang TB Paru Mempengaruhi Penggunaan Masker Di Ruang Paru
Rumkital Dr. Ramelan Surabaya. Jurnal Ilmiah Kesehatan. Vol 7. No. 12. Surabaya : STIKES Hang Tuah

Niven. (2008). Psikologi Kesehatan: Pengantar Untuk Perawat Dan Profesional.EGC Jakarta

Pramita D S,Sholihah N, Atiqoh (2020) Hubungan Antara Pengetahuan Masyarakat Dengan Kepatuhan Penggunaan Masker Sebagai Upaya Pencegahan Penyakit Covid 19 Di Ngronggah. NFOKES, Vol. 10 No 1, Februari 2020. ISSN : $2086-2628$

Priyanto, Agus. (2018). Hubungan Tingkat Pengetahuan Dengan Perilaku Pencegahan Kekambuhan Luka Diabetik. Jurnal Ners Dan Kebidanan. Vol. 5 No. 3. Kediri : STIKES Ganesha Husada

Rita L, Atkinson (2010) Pengantar Psikologi. Erlangga. Jakarta

Riyanto, A. (2013). Statistik Deskriptif Untuk kesehatan. Nuha Medika. Yogyakarta.

World Health Organization (WHO). (2020). Rational use of personal protective equipment for coronavirus disease 2019 (COVID-19) 